\title{
Tinjauan Aspek Tanah Dalam Pengelolaan Daerah Rawa Pasang Surut Di Kalimantan Selatan
}

\author{
Akhmad Gazali, Fathurrahman ${ }^{2}$ \\ ${ }^{1,2}$ Program Studi Teknik Sipil, Fakultas Teknik, Universitas Islam Kalimantan MAB Banjarmasin, Jl. Adhyaksa \\ No. 2 Kayu Tangi Banjarmasin, Kalimantan Selatan (70123), Email: akhmadgazali51@gmail.com
}

\begin{abstract}
Abstrak
Lahan rawa merupakan lahan yang potensial digunakan untuk usaha pertanian, kehutanan dan konservasi sumber air. Para pakar berbeda pendapat mengenai luas lahan rawa di Indonesia. Perkiraan luas lahan rawa ada yang menafsirkan 34 juta hektar, ada juga yang menafsirkan 39,5 juta hektar.

Berdasarkan proses pembentukannya, rawa dibedakan menjadi rawa dalam/lebak dan rawa pasang surut. Rawa pasang surut cenderung lebih banyak dikembangkan mengingat proses reklamasi berjalan lebih cepat. Berdasarkan perkiraan bahwa rerata jangkauan pengaruh pasang surut yang $100 \mathrm{~km}$ dari muara sungai besar, maka luas lahan yang berpotensi menjadi lahan pasang surut adalah sekitar 25-30 juta hektar. Lahan pasang surut ini umumnya terdapat di pantai-pantai Kalimantan, Sumatera dan Irian Jaya.

Sistem reklamasi yang pernah dan masih dilakukan khususnya di Kalimantan Selatan tergantung kondisi tanah dan airnya, ada beberapa kondisi tanah rawa antara lain tanah rawa potensial, sulfat masam dan gambut. Proses reklamasi terus berkembang dengan telah diketemukannya kisaran komposisi senyawa organik dan sifat kimia tanah gambut pada berbagai kedalaman. Diakui terdapat berbagai kendala seperti fisik tanah, kimia tanah dan beberapa kendala lainnya, namun prospek pengelolaan tanah gambut cukup baik untuk tanaman budidaya. Hasil penelitian dan pengalaman menunjukkan bahwa dengan pengelolaan yang tepat dapat diperoleh produktivitas yang cukup tinggi pada tanah gambut.
\end{abstract}

Keywords: Rawa Pasang Surut, Tanah Gambut, Produktivitas Reklamasi, Kalimantan Selatan

\section{Pendahuluan}

Lahan rawa adalah lahan genangan air secara alamiah yang terjadi terus-menerus atau musiman akibat drainase yang terhambat serta mempunyai ciri-ciri khusus secara fisika, kimiawi dan biologis. Lahan rawa merupakan lahan yang potensial digunakan untuk usaha pertanian, kehutanan, konservasi atau sumber air. Para pakar berbeda pendapat mengenai luas lahan rawa di Indonesia. Prakiraan luas lahan rawa ada yang menafsirkan 34 juta hektar, ada juga yang menafsirkan 39,5 juta hektar. Berdasarkan atas tabiat dan kemungkinan proses pembentukannya rawa dibedakan menjadi rawa dalam/lebak dan rawa pasang surut. Rawa pasang surut cenderung lebih banyak dikembangkan mengingat proses reklamasi dapat berjalan lebih cepat. Berdasarkan perkiraan bahwa rerata jangkauan pengaruh pasang surut yang $100 \mathrm{~km}$ dari muara sungai besar, maka luas lahan yang berpotensi menjadi lahan pasang surut adalah sekitar 25 - 30 juta hektar. Lahan pasang surut ini umumnya terdapat di pantai-pantai Kalimantan, Sumatera dan Irian Jaya.

Pemanfaatan lahan rawa dengan skala besar dimulai sejak orde baru, terutama untuk transmigrasi. Akhir-akhir ini lahan pasang surut sebagian dimanfaatkan untuk Hutan Tanaman Industri (HTI), perikanan dan sebagainya. Reklamasi lahan dijalankan dengan membuat tata saluran drainase/pengatusan dan irigasi/pengairan yang dihubungkan dengan sungai utama. Sebelum lahan dibuka, telah diadakan survey tata air, topografi dan tanah yang diwujudkan dalam bentuk tata ruang unit pemukiman. Lahan bermasalah terutama adalah lahan dengan gambut tebal dan lahan sulfat masam, keduanya dinilai tidak layak untuk areal pertanian dan tidak disarankan untuk direklamasi.

Fisiologi lahan yang datar sampai cekung dengan penghambatan pengatusan (drainage) merupakan faktor yang menyebabkan terbentuknya rawa. Keberadaan genangan air yang semula berasal dari daerah lain menyebabkan material yang terikut akan terendapkan (biasanya dalam ukuran koloid). 


\section{Tinjauan Aspek Tanah Dalam Pengelolaan Daerah Rawa Pasang Surut \\ Di Kalimantan Selatan}

Proses pengisian bahan endapan tersebut akan mengikuti perubahan iklim yang terjadi menurut ukuran umur geologi.

Sebagian besar pengisian terbentuk pada periode Holocene (10.000 tahun yang lalu) melalui peningkatan suhu yang berdampak pada pencairan es di daerah kutub sehingga permukaan air laut meningkat secara perlahan hingga mencapai maksimum sekitar $5 \mathrm{~m}$ dari muka air laut sekarang pada 5.000 tahun yang lalu. Peningkatan muka air laut dengan iklim yang agresif menyebabkan proses erosi dan deposisi berjalan intensif, terbentuk endapan gambut (kebanyakan terbentuk dari tumbuhan yang ada di atasnya) dan endapan bahan mineral (berasal dari lahan atasan). Bahan terendapkan tersebut dapat terjadi dalam suasana tawar, payau atau masin. Dalam kondisi payau dan masin terjadi pengalihrupaan tipe koloid lempung dan kemungkinan pembentukan pirit. Endapan gambut terbentuk akibat proses dekomposisi tidak dapat mengimbangi proses deposisi, terutama disebabkan oleh penghambatan aktivitas mikrobia perombak akibat suasana yang reduktif. Sejak 5.000 yang lalu iklim berubah dan muka air laut menurun dan timbunan bahan endapan (mineral atau gambut) yang semula tergenang akan berada di atas permukaan air (Geyh et al., 1979). Keadaan tersebut dapat menyebabkan terjadinya proses oksidasi/peruraian bahan organik dan pirit, yang selanjutnya akan terlindi. Kesudahan proses tersebut menyebabkan lingkungan menjadi lebih masam. Kondisi seperti ini terutama terjadi di daerah yang tidak langsung dipengaruhi oleh pasang surut air payau.

Berlatar belakang hal tersebut diatas, maka tujuan penelitian ini adalah sebagai berikut: (1) Mengetahui sistem reklamasi yang dilakukan selama ini pada tanah gambut. (2) Mengetahui dari segi ketergantungan dari apakah pelaksanaan reklamasi pada tanah gambut. (3) Mengetahui kendala apa yang ditemui dari pelaksanaan reklamasi pada tanah gambut. (4) Mengetahui prospek produktivitas dari pengembangan pengelolaan tanah gambut.

\section{Tinjauan Pustaka}

Daerah rawa pasang surut di Kalimantan secara umum terbentuk pada zaman Holocene dengan variasi umur antara 4.000 sampai 5.000 tahun. Pakar lain menyebutkan angka 700 sampai 5.000 tahun, semakin mendekati pantai umurnya semakin muda (Prasetyo et al., 1990). Dalam proses sedimentasi pada waktu pembentukannya tercampur dengan koloid anorganik yang pada umumnya terdiri atas mineral lempung tipe $2 / 1$. Bahan endapan yang berupa koloid berasal dari daerah atasan yang sudah terbentuk secara stabil sejak zaman tersier, Bahan tersebut relatif sudah berupa bahan sisa dan tahan terhadap dekomposisi/ pelapukan, akibatnya bahan yang terbawa relatif merupakan bahan yang lebih miskin. Daerah pasang surut di Sumatera pada umumnya lebih baik/kaya dibanding dengan daerah Kalimantan. Hal ini terjadi mengingat daerah atasan (hinterland) di Sumatera selalu diperbaharui dengan keberadaan gunung berapi yang masih aktif sampai zaman Pleistocene-Holocene.

Tanah rawa terbentuk akibat proses sedimentasi bahan mineral dan organik yang dapat berasal dari hasil pengikisan daerah atasan, terlonggok dalam suasana kahat udara, yang mengakibatkan kegiatan biologis di dalam tanah tersebut terhambat. Bila proses pengendapan tersebut terjadi pada suasana air tawar, maka akan terbentuk tanah mineral/gambut yang bebas dari pirit. Kalau proses pembentukan bahan tanah dipengaruhi oleh laut, akan terjadi sedimen mineral/gambut yang disertai oleh komponen reduktif besi dan sulfur berbentuk pirit. Kemasaman potensial akan terbentuk bila alkalinitas yang dihasilkan (sebagai bikarbonat) selama proses reduksi sulfat dan besi, feri terlindi keluar dari lingkungannya. Pada tanah yang dipengaruhi oleh aktivitas pasang surut, pembawaan bahan alkalinitas akan mempercepat proses pembentukan pirit. Persyaratan lingkungan yang mampu membentuk pirit yang bila kadarnya cukup akan menjadi tanah potensial sulfat masam, sebagai berikut:

1. Tersedianya sulfat secara berkesinambungan (umumnya dari air laut).

2. Mineral yang cukup mengandung besi di dalam sedimen.

3. Bahan organik yang dapat dirombak.

4. Bakteri pereduksi sulfat, yang umumnya selalu ada.

5. Lingkungan anaerob/tereduksi.

6. Sedikit aerasi yang memungkinkan sulfida teroksidasi menjadi disulfida. 


\section{Tinjauan Aspek Tanah Dalam Pengelolaan Daerah Rawa Pasang Surut}

Di Kalimantan Selatan

\section{Metode Penelitian}

Bentuk dari penelitian ini adalah penggabungan antara pengamatan di lapangan dan pustaka atau literatur yang terkait, beberapa hasil penelitian yang terkait dengan topik ini dirangkum, dihubungkan dengan pelaksanaan yang sedang berlangsung di lapangan, dalam menentukan lokasi diambil dari lokasi yang berhubungan dengan topik dari penelitian ini yaitu terletak di Provinsi Kalimantan Selatan dan Provinsi Kalimantan Tengah. Di Provinsi Kalimantan Selatan tepatnya di Kabupaten Barito Kuala sedangkan di Kalimantan Tengah di Kabupaten Kapuas.

Pengumpulan data berupa dua macam data yaitu data primer dan data sekunder. Data primer diperoleh dengan cara berhubungan langsung dengan objek penelitian yaitu berupa wawancara dan observasi, sedangkan data sekunder diperoleh dengan melakukan studi pustaka atau literatur yang terkait dengan topik penelitian tersebut.

\section{Analisis dan Pembahasan}

\subsection{Jenis Tanah di Daerah Rawa}

Tanah yang terbentuk akibat hasil pelonggokan bahan mineral atau organik atau kombinasi keduanya meskipun prosesnya tidak aktif lagi, masih dikategorikan sebagai tanah yang muda. Tanah tersebut belum mengalami proses pedogenesis yang mencakup keberadaan eluviasi dan illuviasi. Tanah yang terbentuk belum menunjukkan pencirian horison diagnostik, sehingga di dalam sistem klasifikasi USDA yang umum dipakai dewasa ini disebut sebagai Entisol. Karena proses pembentukan tanahnya berupa sedimentasi, maka dalam sistem klasifikasi lama disebut tanah Aluvial. Tanah tersebut disebut juga sebagai tanah Hidromorfik dengan ciri kelebihan air dari kekurangan oksigen di dalam tanah.

Kriteria yang dipakai pada klasifikasi tanah di daerah rawa pada umumnya adalah: macam bahan penyusun (organik/gambut dan mineral), ketebalan (terutama untuk gambut), keberadaan/sebaran pirit pada solum tanah (dangkal atau dalam), pengaruh air laut (payau dan masin). Bahan penyusun berupa tanah mineral dapat dibedakan dengan gambut dengan memperhatikan imbangan kadar lempung (clay) dan kadar karbon organik di dalam tanah tersebut. Dikatakan tanah mineral bila kadar lempung $0 \%$ dan kadar karbon organik $<12 \%$; bila kadar lempung $60 \%$ maka kadar karbon organiknya $<18 \%$; bila kadar lempung antara $0-60 \%$, maka imbangan kandungan karbon organiknya mengikut proporsi seperti di atas. Tanah dikatakan organik bila keadaannya berkebalikan dengan ketentuan di atas.

Disamping bahan tanahnya, juga ketebalan sangat berperan dalam sistem klasifikasi. Disebut tanah mineral bila ketebalannya $<40 \mathrm{~cm}$ kalau tingkat perombakan gambutnya setengah matang atau matang; dan $<60 \mathrm{~cm}$ bila kematangan gambutnya relatif mentah. Bila kandungan lempung dan bahan organik keduanya relatif tinggi dan masih masuk kategori tanah mineral, biasanya tanah tersebut dapat juga disebut sebagai tanah lempung gambutan (peaty clay). Tanah gambut sendiri dipilahkan lebih lanjut menjadi gambut tipis dan gambut tebal, kriteria batasan ketebalan tersebut beraneka dan berkisar antara $100-150 \mathrm{~cm}$, bahkan ada yang berpendapat $50 \mathrm{~cm}$. Keberadaan pirit yang menunjukkan tanah Potensial Sulfat Masam pada solum dipisahkan menjadi dangkal $(<50 \mathrm{~cm})$ dan dalam $(>50 \mathrm{~cm})$. Selanjutnya tanah disebut sebagai Aktual Sulfat Masam bila pirit teroksidasi.

Tanah sulfat masam aktual pada umumnya tersebar di daerah yang telah cukup lama direklamasi dan biasanya terletak di sekitar daerah pantai. Tanah yang dianggap potensial adalah tanah mineral dan tanah lempung gambutan yang tidak mengandung pirit sampai kedalaman $100 \mathrm{~cm}$. untuk tanah sulfat masam potensial yang dikumpulkan dari hasil survei di Kalimantan dan Sumatera menunjukkan bahwa dari total 805.834 ha terdapat 259.424 ha $(32,19 \%)$ tanah yang dikategorikan sebagai tanah sulfat masam. Bila hal ini dapat dipakai untuk mewakili lahan pasang surut, maka luasan tanah sulfat masam di Indonesia adalah 9,7 juta ha. Berarti prakiraan 2 juta ha (Driessen dan Soepraptohardjo, 1974), 1,5 juta (FAO, 1974), dan 5,5 juta ha (Nugroho et al., 1998) adalah taksiran yang lebih rendah dari taksiran di atas. Tanah rawa medium dan dalam mencerminkan ketebalan air yang menggenangi tanah rawa tersebut, dikatakan dalam bila air genangan $>100 \mathrm{~cm}$. 
Penyebaran tanah gambut terutama terletak pada lahan pasang surut, meskipun ada pula di rawa yang bukan pasang surut. Berdasarkan hasil survey-survey yang telah dilakukan oleh berbagai perguruan tinggi dan PPPTA (Bogor) menunjukkan bahwa tanah gambut cukup luas di lahan pasang surut. Hasil survey dari 39 lokasi di Kalimantan dan Sumatera menunjukkan bahwa 47,71\% dari luas areal yang disurvey terdiri atas tanah gambut dengan berbagai ketebalan, $10,05 \%$ tanah gambut dengan ketebalan 20 sampai $40 \mathrm{~cm}$ dan 37,66\% tanah gambut dengan ketebalan lebih dari $40 \mathrm{~cm}$. Kalau data survey tersebut digunakan sebagai patokan dengan prakiraan luas lahan pasang surut di Indonesia 30 juta ha, maka luas tanah gambut sekitar 11,30 juta ha (hampir seluas pulau Jawa). Kalau diperinci lebih lanjut, maka tanah gambut dengan ketebalan antara $20-40 \mathrm{~cm}$ seluas hampir 3 juta ha dan tanah gambut dengan ketebalan lebih dari $40 \mathrm{~cm}$ seluas $+8,3$ juta ha. Gambut matang (Saprist) akan ada seluas 2,78 juta ha, gambut agak matang (Hemist) 4,62 juta ha, dan gambut mentah (Fibrist) adalah 0,90 juta ha.

\subsection{Potensi dan Karakteristik Lahan Rawa Pasang Surut}

Berdasarkan kompilasi beberapa peta rawa yang dilakukan BBSDLP (2014), diketahui bahwa luas rawa di Indonesia sebesar 34.926.551 ha (Tabel 1). Peta sebaran lahan rawa di Indonesia disajikan pada Gambar 1.

Tabel 1. Perkiraan Luas Lahan Rawa di Indonesia

\begin{tabular}{|l|c|c|c|c|}
\hline \multicolumn{1}{|c|}{ Pulau Besar } & $\begin{array}{c}\text { Rawa Pasang } \\
\text { Surut }\end{array}$ & Rawa Lebak & Rawa Gambut & Total Luas \\
\hline & \multicolumn{4}{|c|}{ x 1.000 ha...................... } \\
\hline Sumatera & 2.501 .888 & 3.988 .301 & 6.436 .649 & 12.926 .835 \\
\hline Jawa & 896.122 & 0 & 0 & 896.122 \\
\hline Kalimantan & 2.301 .410 & 2.944 .085 & 4.778 .005 & 10.023 .500 \\
\hline Sulawesi & 318.030 & 706.220 & 23.844 & 1.048 .094 \\
\hline Maluku & 74.395 & 88.159 & 0 & 162.554 \\
\hline Papua & 2.262 .402 & 3.916 .123 & 3.690 .921 & 9.869 .446 \\
\hline Indonesia & $\mathbf{8 . 3 5 4 . 2 4 7}$ & $\mathbf{1 1 . 6 4 2 . 8 8 8}$ & $\mathbf{1 4 . 9 2 9 . 4 1 6}$ & $\mathbf{3 4 . 9 2 6 . 5 5 1}$ \\
\hline
\end{tabular}

Sumber: BBSDLP (2014)

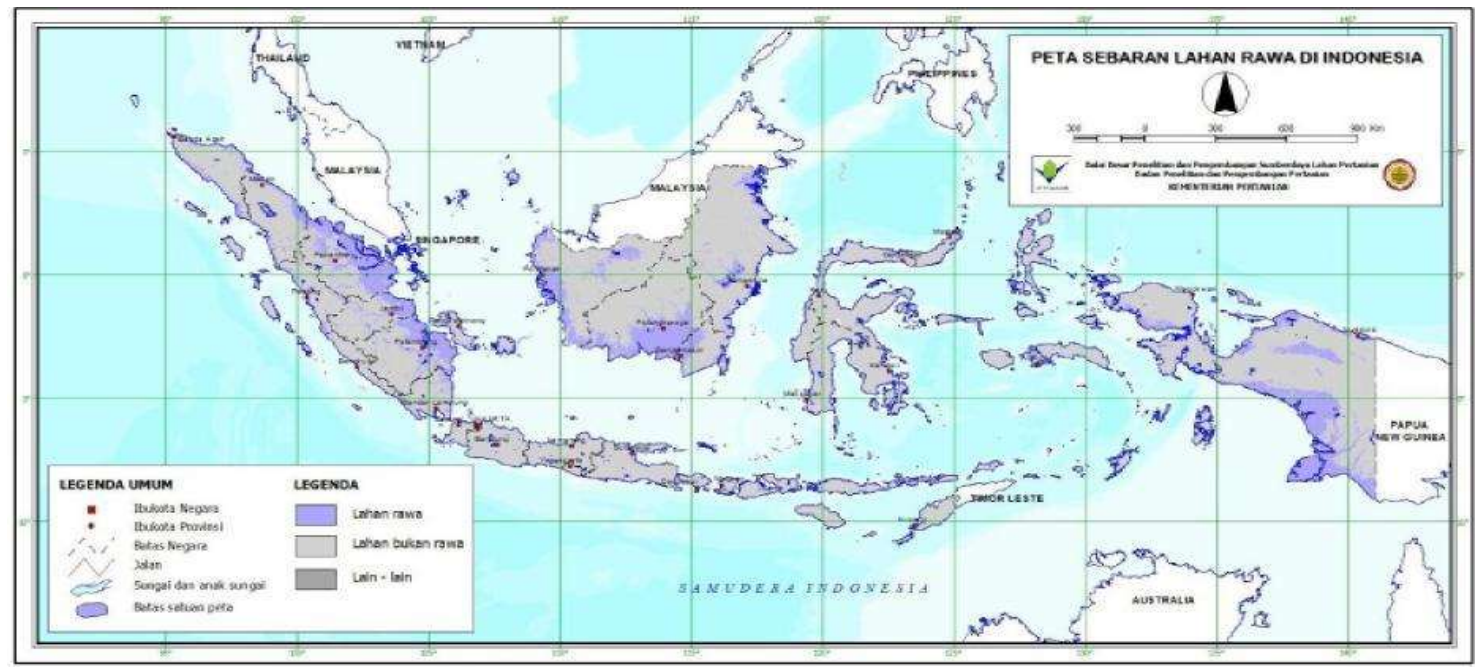

Sumber: BBSDLP (2014)

\section{Gambar 1. Sebaran Lahan Rawa di Indonesia}

Lahan pasang surut adalah lahan yang rejim airnya dipengaruhi oleh pasang surutnya air laut atau sungai. Badan Litbang Pertanian membagi tipe luapan air lahan pasang surut berdasarkan pasang siklus bulanan menjadi tipe luapan A, B, C dan D (Widjaja-Adhi 1986, Kselik 1990). Lahan bertipe 
luapan A selalu terluapi air pasang, baik pada musim hujan maupun musim kemarau, sedangkan lahan bertipe luapan B hanya terluapi air pasang pada musim hujan saja. Lahan bertipe luapan C tidak terluapi air pasang tetapi dipengaruhi muka air tanahnya dengan kedalaman kurang dari $50 \mathrm{~cm}$, sedangkan lahan bertipe luapan D adalah seperti tipe $C$ hanya kedalaman air tanahnya lebih dari 50 $\mathrm{cm}$. Karakteristik contoh tanah dari berbagai tipologi dan tipe luapan air di lahan pasang surut Kalimantan Selatan dan Tengah disajikan pada Tabel 2.

Tabel 2. Sifat Fisiko-Kimia Tanah Lapisan Atas $(0-30 \mathrm{~cm})$ pada Berbagai Tipologi dan Tipe Luapan Air di Lahan Pasang Surut Kalimantan Selatan dan Kalimantan Tengah

\begin{tabular}{|l|c|c|c|c|}
\hline \multirow{2}{*}{ Sifat Fisiko-Kimia Tanah } & Lahan Sulfat Masam & \multicolumn{3}{|c|}{ Lahan Sulfat Masam Aktual } \\
\cline { 2 - 5 } & Potensial Tipe A & Tipe B & Tipe C & Tipe B/C \\
\hline pH & 5,31 & 3,94 & $3,70-3,69$ & $3,46-4,74$ \\
\hline C-organik (\%) & 4,55 & 9,75 & $7,10-7,50$ & $4,0-6,97$ \\
\hline N-total (\%) & 0,20 & 0,59 & $0,27-0,48$ & $0,12-0,21$ \\
\hline P2O5 tersedia (ppm) & 25,3 & - & $0,25-23,55$ & 1,57 \\
\hline EC (uS/cm) & 561,5 & 172,0 & 301,0 & 40,0 \\
\hline Kation dapat dipertukarkan: & & & & \\
\hline K (cmol/kg) & 0,70 & 0,40 & 0,32 & 2,04 \\
\hline Na (cmol/kg) & 4,65 & 0,15 & 0,39 & 2,76 \\
\hline Al (cmol/kg) & 0,60 & 7,50 & 13,25 & 5,21 \\
\hline Kejenuhan basa (\%) & 81 & 26 & - & $4,40-28,78$ \\
\hline Tekstur: & & & & \\
\hline Liat (\%) & 56 & 36 & 56 & 54 \\
\hline Debu (\%) & 43 & 61 & 43 & 45 \\
\hline Pasir (\%) & 1 & 3 & 1 & 1 \\
\hline
\end{tabular}

Lahan rawa pasang surut potensial dan strategis dikembang sebagai lahan pertanian, dapat menjadi sumber pertumbuhan baru produksi (komoditas) pertanian, karena mempunyai beberapa keunggulan antara lain: (1) tersedia cukup luas dan berada dalam satuan-satuan skala hamparan yang cukup luas, (2) ketersediaan air berlebih, (3) topografi rata atau datar, (4) akses ke daerah pengembangan dapat melalui jalur darat dan jalur air sehingga memudahkan jalur distribusi, dan (4) kesesuaian lahan dan agronomi cukup sesuai sampai sangat sesuai. Beragam komoditas berhasil dikembangkan di lahan rawa meliputi tanaman pangan (padi dan palawija), hortikultura (sawi, terung, semangka, jeruk, nenas dsb) dan perkebunan (kelapa, karet, dan kelapa sawit).

Walaupun lahan rawa pasang surut potensial dan strategis dikembangkan sebagai lahan pertanian, lahan ini mempunyai beberapa permasalahan dari segi kesuburan tanah, antara lain $\mathrm{pH}$ tanah dan kandungan hara yang rendah, kandungan $\mathrm{Fe}$ dan aluminium yang tinggi, genangan air yang sering tidak dapat dikendalikan (Purnomo et al. 2005), serta kandungan H2S dan Mn yang dapat mencapai tingkat racun (Andriesse dan Sukardi 1990). Tanah sulfat masam jika mengalami oksidasi karena didrainase akan menghasilkan logam $\mathrm{Fe}$ dalam jumlah yang mencapai racun dan kemasaman yang sangat tinggi (Shamshuddin et al. 2004).

\subsection{Reklamasi Tanah Rawa}

Tujuan reklamasi lahan rawa adalah penciptaan lingkungan baru yang sesuai dengan lingkungan yang dikehendaki oleh sistem pertanaman, terutama tanaman pangan. Penciptaan lingkungan ini berkaitan dengan pembuangan kelebihan air yang mampu membuat imbangan serasi air-udara dalam tanah. Karena kondisi alamiah rawa yang langka udara (reduktif), pengubahan suasana ke arah oksidatif akan membawa konsekuensi perubahan perwatakan tanah. Proses perubahan ini terutama terjadi secara kimiawi, di samping perubahan biologis dan mekanis/fisik. Perubahan yang timbul merupakan kebalikan kejadian/proses yang telah berlangsung sewaktu terbentuknya tanah rawa tersebut. Kalau pada waktu pembentukan terjadi perubahan suasana oksidatif ke reduktif yang banyak mengeluarkan alkalinitas, maka proses oksidasi dalam reklamasi akan mengeluarkan kemasaman. Mengingat proses 
pembentukan tanah rawa memakai ukuran waktu geologis, maka proses reklamasi pun tentunya juga memerlukan jangka waktu cukup lama untuk mencapai taraf kesudahan (ultimate stage). Konstruksi bangunan keteknikan sering hanya mengandalkan mekanisme pergerakan air, tanpa mengindahkan perubahan perwatakan sifat lahan rawa itu sendiri. Tiap tipologi/ jenis tanah lahan rawa akan membutuhkan pengelolaan yang dapat sangat berbeda dengan jenis/tipologi lainnya. Keragaman jenis tanah yang didasarkan atas satuan pengelolaan atau unit reklamasi sangat sukar didapatkan, berbagai interaksi proses dapat berlangsung selama rawa tersebut dibentuk.

Proses reklamasi di tanah mineral pada umumnya berlangsung sangat cepat pada awalnya (3-6 bulan setelah saluran pengatus berjalan) dan cenderung menurun pada periode berikutnya. Proses tersebut tetap berjalan sampai dicapai kesetimbangan sewaktu mencapai kondisi aerobik seperti halnya di tanah bukan rawa. Di tanah gambut kondisinya hampir sama, hanya saja kelangsungan degradasi lanjutan memerlukan waktu yang sangat lama. Kelanjutan proses dekomposisi/degradasi bahan organik tersebut disamping akan menyisakan bahan-bahan yang resisten terhadap dekomposisi.

Selama air atusan yang keluar dari tanah gambut masih berwarna kuning kecoklatan, dapat diartikan bahwa proses reklamasi masih terus berlanjut. Selama proses berlangsung akan terproduksi sumbersumber kemasaman tanah (baik ion $\mathrm{H}$ maupun ion $\mathrm{Al}$ ), yang secara berkesinambungan berfungsi sebagai ion penukar pada kation lain yang berada dalam tapak pertukaran. Kesudahannya dapat diduga bahwa tanah bereaksi semakin masam dan kejenuhan aluminium semakin meningkat.

Untuk tetap dapat memanfaatkan lahan rawa sebagai lahan pertanian dengan baik, setelah pekerjaan tata air selesai, maka sampai saat ini sistem reklamasi lahan rawa pasang surut menganut sistem usikan minimum. Prinsip sistem ini adalah mengusahakan agar perubahan kondisi tanah terjadi secara perlahan-lahan dengan pengaturan tinggi muka air tanah, dan menggunakan sistem pengolahan tanah minimum tillage. Dengan cara demikian pelepasan kemasaman jumlahnya relatif sedikit akibat Oksidasi terbatas akan mudah tercuci atau terhanyutkan melalui saluran pembuang. Cara ini cukup jitu bila tidak ada penghambatan pada sistem tata airnya. Tetapi seringkali jumlah dan kualitas air sangat bervariasi (terutama akibat musim), yang berakibat pada percepatan proses oksidasi. Semakin sering frekuensi fluktuasi air tersebut semakin cepat pula proses degradasi tanah akan terjadi.

Sistem reklamasi lain yang pernah dilakukan adalah dengan membuat saluran dalam, sehingga muka air tanah jauh dari permukaan tanah dan lahan tidak/jarang terluapi. Kejadian ini bila disertai dengan pengolahan tanah intensif akan sangat memacu proses oksidasi, sehingga dalam waktu yang relatif singkat sebagian besar potensi kemasaman akan dapat dikeluarkan.

\subsection{Tanah Rawa Potensial}

Tanah rawa pasang surut yang tidak mengandung pirit dan gambut tebal serta bertekstur halus adalah tanah yang berpotensi dikembangkan untuk pertanian. Reklamasi mengakibatkan perubahan lingkungan reduktif menjadi oksidatif. Oksidasi anasir tereduksi (terutama besi dan bahan organik) masih memungkinkan terjadinya proses pemasaman tanah, terlebih bila sistem tata air tidak mendukung. Disamping pengaturan tata air yang baik, pemupukan dan pemberian bahan penetral/penukar kemasaman perlu dikerjakan untuk membuat tanah ini tetap produktif.

\subsection{Tanah Sulfat Masam}

Tanah sulfat masam terbentuk dalam suasana marin, kebanyakan terdapat pada lahan pasang surut. Disini disebut tanah sulfat masam bila terdapat bahan pirit pada kedalaman $<1 \mathrm{~m}$ dari permukaan tanah dengan kadar $>0,75 \%$ dan tidak cukup banyak tersedia bahan alkalinitas untuk menetralkan kemasaman yang timbul akibat oksidasi pirit tersebut. Tanah seperti ini tidak direkomendasikan untuk direklamasi mengingat akan teroksidasinya pirit dengan membentuk asam sulfat dan membuat $\mathrm{pH}$ tanah menjadi luar biasa masam $(<4,0)$. 


\section{Tinjauan Aspek Tanah Dalam Pengelolaan Daerah Rawa Pasang Surut \\ Di Kalimantan Selatan}

Pengamatan di lapangan pada daerah sulfat, masam potensial yang tidak terkena pengaruh penyusupan air payau, pertanaman kelapa baru dapat berhasil setelah 2-4 kali penyulaman karena bibit selalu mati. Bagi daerah yang terkena pengaruh susupan air payau keadaan tersebut jarang terjadi, hal ini membuktikan bahwa air payau mampu menurunkan kadar ion Al yang ada di dalam tanah. Percobaan Maas (1989) mendukung prakiraan tersebut. Peranan susupan air tanah yang bersuasana payau melalui kapiler mampu menekan kejenuhan aluminium sampai $44 \%$ terhadap kontrol, dan perbaikan kation tertukarkan (Maas, 1989).

\subsection{Tanah Gambut}

Gambut adalah tanah yang tersusun dari lapukan sisa tanaman dengan berbagai tingkat dekomposisi, terdiri atas bahan humin, asam-asam organik, protein, lemak dll. Meskipun susunannya tidak sepenuhnya menyerupai bahan organik tanah mineral, akan tetapi gambut mempunyai kompleks jerapan baik terhadap anion maupun kation. Gambut yang ada di Indonesia mencapai luasan sekitar 18,0 juta ha, umumnya bersifat masam, nisbah $\mathrm{C} / \mathrm{N}$ tinggi dan miskin hara tersediakan. Nilai $\mathrm{C} / \mathrm{N}$ yang tinggi menunjukkan bahwa bahan penyusun gambut tersebut masih berupa senyawa karbon dengan rantai yang panjang, hal ini menyebabkan sebagian hara total masih merupakan bahan penyusun struktur sel/bahan humin, atau rantai karbon yang panjang tadi.

Kation asam polivalen seperti aluminium dan besi dapat membentuk kelasi dengan bahan organik, baik yang terlarut maupun yang berupa koloid. Tidak semua muatan positif dinetralisasi oleh koloid, ada kelebihan muatan yang dapat menangkap anion bebas yang berada dalam larutan tanah. Secara umum dapat dikatakan bahwa polianion akan ditarik/disemat lebih kuat daripada anion monovalen. Disamping itu, muatan positif koloid organik secara langsung juga akan dapat menjerap anion. Dengan demikian perlu diteliti karakterisasi kemasaman gambut dan sumber asamnya yang berperan dalam jerapan anion polivalen (seperti misalnya ion fosfat). Semakin tebal dan semakin mentah tanah gambut maka akan semakin rendah pula kelas kesesuaian lahannya sebagai areal pertanian. Angka ketebalan $>150 \mathrm{~cm}$ umumnya dinilai tidak layak untuk digunakan sebagai pertanaman semusim.

Tumbuhan sebagai bahan penyusun/asal gambut secara umum mengandung karbohidrat, protein, lipid, dan polyphenol (seperti lignin). Selain itu terdapat juga sejumlah kecil asam nukleat, pigmen, alkaloid, vitamin dan senyawa organik lain yang bergabung dengan senyawa anorganik. Gula merupakan karbohidrat paling cepat dimetabolisme oleh mikroorganisme, juga pati akan segera dirombak menjadi gula oleh reaksi ensimatis menjadi gula yang siap untuk bahan metabolisme. Hemicellulose, pektin dan guiti terombak lebih lambat) dan cenderung masih ada dan bersama dengan cellulose sebagai salah satu komponen penyusun gambut.

\subsection{Kendala Fisik Tanah Gambut}

Tanah gambut mempunyai kerapatan lindak (baik density) yang rendah yakni $0,1 \mathrm{~g} \mathrm{~cm}-2$. Kerapatan lindak yang nisbi tinggi dijumpai dibagian tepi kubah karena adanya campuran lempung. Porositas tanah gambut nisbi tinggi yakni antara 80-95\%, sedangkan daya hantar lengas vertikalnya rendah, tetapi ke arah horizontal tinggi. Tanah gambut mempunyai daya ikat lengas tinggi $( \pm 100 \%$ atas dasar berat), tetapi bersifat menolak air (hydrophobic) apabila terlalu kering.

Setelah drainasi dan pembukaan lahan, umumnya terjadi subsidensi (subsidence) yang relatif cepat, yang berakibat turunnya permukaan tanah. Subsidensi dan dekomposisi bahan organik dapat menimbulkan masalah apabila bahan di bawah lapis gambut adalah pirit $\left(\mathrm{FeS}_{2}\right)$ atau pasir kuarsa. Kerapatan lindak yang rendah berakibat kemampuan menahan (bearing capacity) tanah gambut juga rendah, sehingga pengolahan tanah sulit dilakukan secara mekanis atau dengan ternak kerja. Kemampuan menahan yang rendah juga merupakan masalah untuk tanaman pohon-pohonan maupun tanaman semusim yang rentan terhadap kerebahan (lodging). 


\section{Tinjauan Aspek Tanah Dalam Pengelolaan Daerah Rawa Pasang Surut}

Di Kalimantan Selatan

\subsection{Kendala Kimia Tanah Gambut}

Tanah gambut ombrogen mempunyai $\mathrm{pH}$ yang rendah berkisar antara 3-5, dan menurun bersama jeluk. Terdapatnya $\mathrm{pH}$ yang nisbi tinggi $(+5)$ disebabkan seringnya dilakukan pembakaran vegetasi di atas tanah. Ketersediaan unsur-unsur makro N, P, K. serta sejumlah unsur mikro, rendah. Kapasitas Pertukaran Kation (KPK) tanah gambut cukup tinggi apabila dihitung atas dasar berat bahan (115-270 me \%), tetapi nisbi rendah bila dihitung atas dasar volume tanah di lapangan. Kejenuhan basanya nisbi rendah, yakni 5,4-13\%. Nisbah $\mathrm{C} / \mathrm{N}$ tanah gambut nisbi tinggi yakni 24-33,4. Hal ini akibat adanya pengapuran yang terjadi pada pendispersian bahan gambut yang sebagian besar berupa asam humat $21,45 \%$, dan sebagian kecil berupa asam fulvat $(4,8 \%)$. Kedua asam tersebut memegang kunci sebagai KPK tanah $(250->750 \mathrm{me} / 100 \mathrm{~g}$ bahan). Kelarutan dan pelindian fraksi-fraksi tersebut juga tercermin pada status keharaan tanah gambut.

Leiwakabessy \& Wahjudin (1979) menunjukkan adanya hubungan erat antara ketebalan gambut dan produksi gabah padi sawah. Hasil penelitian mereka menunjukkan bahwa hasil gabah padi sawah sangat rendah apabila ketebalan gambut $>80 \mathrm{~cm}$, dan paling tinggi apabila ketebalan gambut $50 \mathrm{~cm}$. Dengan adanya kesamaan pola perubahan kejenuhan $\mathrm{Ca}$, kejenuhan $\mathrm{Mg}, \mathrm{pH}$ dan kandungan abu dengan pola perubahan hasil pada berbagai ketebalan gambut, disimpulkan bahwa kemasaman dan/atau suplai Ca yang rendah, serta kandungan abu yang rendah, merupakan faktor-faktor pembatas utama pertumbuhan tanaman pada gambut tebal. Pengaruh faktor-faktor tersebut diduga kuat berkaitan dengan masalah nutrisi karena pemberian hara lengkap cenderung mengatasi "pengaruh" ketebalan gambut terhadap hasil gabah.

Hasil penelitian lainnya menunjukkan bahwa sangat rendahnya hasil panen padi sawah pada gambut tebal diakibatkan oleh kehampaan gabah (reclamation decease) yang diduga kuat disebabkan oleh kekahatan (deficiency) $\mathrm{Cu}$. Memang sudah lama diketahui bahwa kandungan bahan organik yang tinggi dalam tanah, terutama tanah-tanah berkandungan unsur mikro rendah, berpengaruh negatif pada pertumbuhan padi sawah dan tanaman budidaya lainnya, meskipun ada segi positifnya yakni KPK yang nisbi tinggi. Tanah-tanah gambut mempunyai daya menjerap $\mathrm{Cu}$ yang tinggi karena kandungan substansi-substansi organiknya.

\subsection{Kendala Lainnya}

Subsidensi gambut yang cepat juga menimbulkan masalah dalam hal pengendalian air. Menurunnya permukaan tanah menyebabkan semakin terhambatnya drainase terutama di lahan-lahan pasang surut. Terdapat juga hamparan gambut di daerah pasang surut yang tidak pernah tersuplai air pasang tertinggi, sehingga harus bergantung pada air hujan untuk pengairannya. Disamping itu terjadi pula penurunan $\mathrm{pH}$ tanah menjadi luar biasa masam $(\mathrm{pH}<3,5)$ yang disebabkan oleh terbentuknya asamasam organik dengan kadar tinggi. Bagian yang mudah teroksidasi merupakan bagian yang kaya dengan muatan, bila bagian ini hilang dan terlindi (karena sifat porus dari gambut), maka sifat muatan gambut tersebut sangat berkurang dan menyebabkan status keharaan tanaman menjadi miskin. Pengapuran sering didengungkan untuk meningkatkan $\mathrm{pH}$ tanah, takaran kapur tiap unit volume gambut memang tidaklah besar $\left(<4\right.$ ton ha $\left.{ }^{-1}\right)$, tetapi harus diingat bahwa pemberian bahan alkali kuat (seperti kapur) akan menyebabkan percepatan peruraian gambut tersebut yang menghasilkan humat dan fulvat yang mudah terlindi. Percobaan pengapuran mencapai $\mathrm{pH}$ tetap 5,0, menunjukkan terjadinya pelarutan bahan humin sebanyak 26\% dari berat tanah gambut (Maas, 1989). Pelarutan asam humat dan fulvat yang berwarna kecoklatan tersebut akan sangat merugikan keharaan tanaman, karena sebagian besar hara terkandung dalam kedua fraksi tersebut. 


\subsection{Prospek Pengelolaan Lahan Rawa Pasang Surut}

Berbagai tanaman budidaya mempunyai prospek yang cukup baik untuk diusahakan pada lahan-lahan rawa pasang surut. Namun dapat dikatakan bahwa saat ini perluasan areal pertanian di lahan-lahan rawa pasang surut berjalan lebih cepat daripada perkembangan pengetahuan tentang pengelolaannya.

Produktivitas lahan rawa pasang surut cukup tinggi apabila dikelola dengan baik dan dengan input yang cukup. Dengan aplikasi teknologi Pengelolaan Tanaman Terpadu, produktivitas varietas unggul baru (VUB) untuk lahan rawa dapat ditingkatkan menjadi berkisar antara 3,88 ton GKG ha ${ }^{-1}$ (Inpara 2) sampai 6,56 ton GKG ha-1 (Indragiri) (Endrizal dan Jumakir 2009), namun kebanyakan yang ditanam petani varietas lokal seperti Siam Mutiara dan/atau Siam Saba dengan produktivitas 2.0-3,0 t GKG ha-1 (Noor 2004). Optimalisasi lahan rawa pasang surut sangat strategis dan berpeluang besar untuk meningkatkan produksi padi di lahan rawa pasang surut sehingga berkontribusi signifikan terhadap produksi padi nasional. Optimalisasi tersebut dapat melalui:

\section{a. Perluasan Areal}

Perluasan areal lahan rawa pasang surut terbuka luas karena potensi lahan rawa pasang surut yang cocok untuk pertanian ada sekitar antara 14,97 juta ha (BBSDLP 2014). Angka ini menunjukkan potensi luasan yang cukup besar, sehingga dibutuhkan upaya untuk dapat memanfaatkan lahan ini sebagai sumber produksi pertanian. Gambar 2 memperlihatkan areal lahan rawa pasang surut yang terlantar, lahan ini dapat dibuka dan dimanfaatkan untuk pertanian.
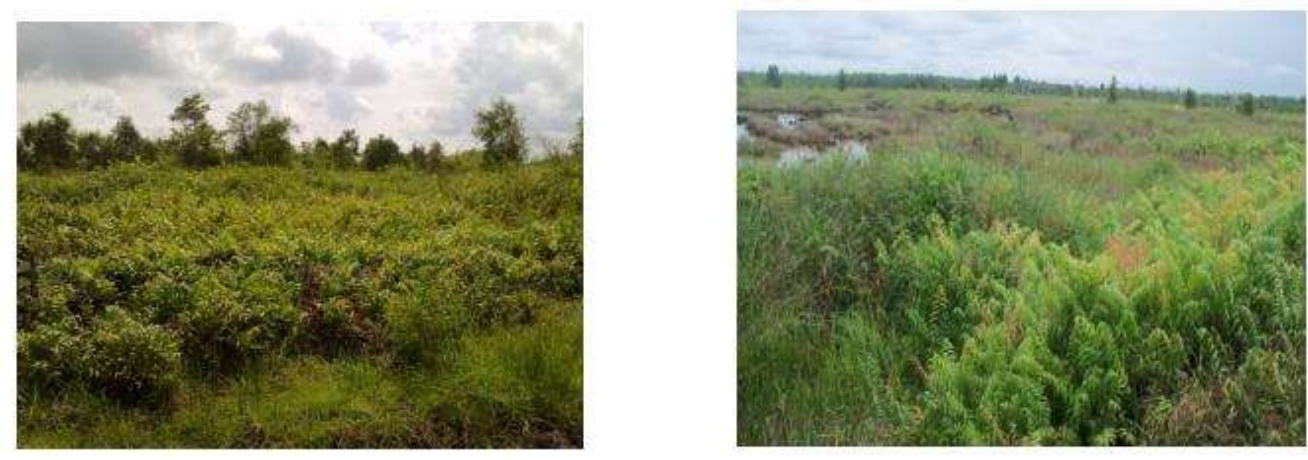

Gambar 2. Lahan Pasang Surut Terlantar di Kabupaten Barito Kuala, Kalimantan Selatan

\section{b. Peningkatan Indeks Pertanaman (IP)}

Indeks Pertanaman di lahan rawa pasang surut masih rendah, yaitu hampir 90\% nya masih tanam sekali dalam setahun (IP 100) seperti di wilayah Tamban Catur, Anjir Serapat, Anjir Muara, dan Karang Indah dan sekitarnya Kabupaten Barito Kuala.

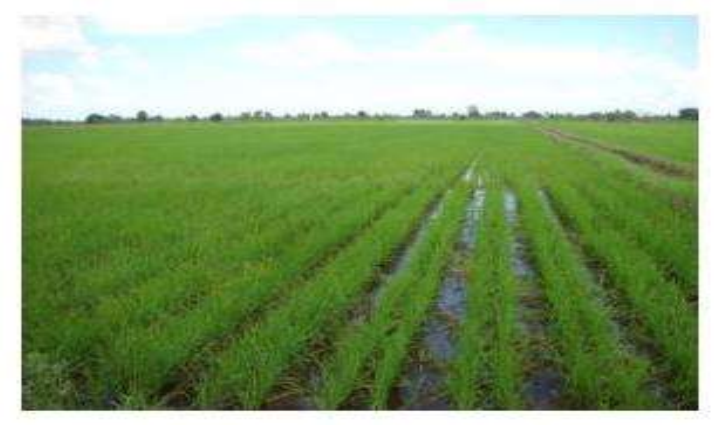

Gambar 3. Sistem Tabela (Tanam Benih Langsung) 


\section{Tinjauan Aspek Tanah Dalam Pengelolaan Daerah Rawa Pasang Surut \\ Di Kalimantan Selatan}

\section{c. Pengelolaan Air}

Pengelolaan air merupakan salah satu faktor penentu keberhasilan pengembangan pertanian di lahan pasang surut dalam kaitannya dengan optimalisasi pendayagunaan dan pelestarian sumberdaya lahannya (Widjaja-Adhi dan Alihamsyah 1998). Pengaturan tata air ini bukan hanya untuk mengurangi atau menambah ketersediaan air permukaan, melainkan juga untuk mengurangi kemasaman tanah, mencegah pemasaman tanah akibat teroksidasinya lapisan pirit, mencegah bahaya salinitas, bahaya banjir, dan mencuci senyawa beracun yang terakumulasi di zona perakaran tanaman (Suryadi et al. 2010). Strategi pengendalian muka air ditujukan kepada aspek upaya penahanan muka air tanah agar selalu di atas lapisan pirit dan pencucian lahan melalui sistem drainase terkendali. Kondisi muka air yang diinginkan sangat tergantung kepada jenis tanaman, jenis tanah, dan kondisi hidrologis wilayah setempat.

Air sebagai bahan pelarut dipakai untuk menghilangkan material yang larut air dan tidak berpengaruh pada kation atau anion yang berada di tapak jerapan. Pencucian atau penukaran akan juga membawa bahan-bahan yang terlarutkan lainnya, terutama asam-asam fulvat atau gugusgugus organik dengan rantai karbon pendek. Keseimbangan larutan dan fase koloid gambut terganggu dan imbangan baru akan lebih dikuasai oleh ion-ion penukar yang pada umumnya merupakan garam-garam netral. Pengapuran dengan dosis tinggi menunjukkan kemampuan karbonat untuk menetralkan asam terlarutkan, tertukar atau yang potensial, sesuai dengan banyaknya penambahan bahan alkalin tersebut. Terlihat peningkatan $\mathrm{pH}$ yang juga diikuti dengan pengurangan asam terlarutkan dalam tanah, aluminium menjadi tidak aktif dan mengendap sebagai A1. $(\mathrm{OH}) 3$. Pengapuran yang melebihi kemasaman potensial menyebabkan terbentuknya sisa $\mathrm{CaCO} 3$ atau $\mathrm{CaHCO} 3$ yang dapat menimbulkan masalah bagi kemangkusan pemupukan anion polivalen.

\section{Kesimpulan}

Adapun kesimpulan dari hasil penelitian ini adalah sebagai berikut:

1. Dalam pelaksanaan reklamasi pasang surut yang dilakukan pada tanah gambut menganut sistem kesesuaian lahan terhadap keterbatasan jenis tanaman yang tergantung dari kondisi keairan (kualitas dan kuantitas).

2. Reklamasi pasang surut pada tanah gambut tergantung dari kondisi dari tanah dan airnya pada tanah gambut tersebut juga tanah rawa potensial, sulfat masam namun proses reklamasi akan terus berkembang dengan telah ditemukannya kisaran komposisi senyawa organik dan sifat kimia tanah gambut pada berbagai kedalaman.

3. Kendala yang dihadapi adalah fisik tanah, kimia tanah dan kendala lainnya.

4. Prospek pengelolaan tanah gambut untuk tanaman budidaya dari hasil penelitian dan pengalaman di lapangan menunjukkan bahwa dengan pengelolaan yang tepat dapat diperoleh produktivitas yang cukup tinggi pada tanah gambut.

\section{Daftar Pustaka}

Andriesse, W. and M. Sukardi. 1990. Survey Component : Introductions, Objective and Out line Papers Workshop on Acid Sulphate Soils in the Humid Tropics. AARD-LAWOO. Jakarta.

BBSDLP. 2014. Sumberdaya Lahan Pertanian Indonesia: Luas, Penyebaran dan Potensi Ketersedian. Bogor. 62 hlm.

Driessen, P.M., and M. Soepraptohardjo, 1974. Soils for agricultural expansion in Indonesia. Soil Research Institute, Bogor.

Endrizal dan Jumakir. 2009. Produktivitas beberapa VUB padi rawa lebak mendukung desa mandiri pangan Kabupaten Batanghari. Balai Pengkajian Teknologi Pertanian Jambi. 


\section{Tinjauan Aspek Tanah Dalam Pengelolaan Daerah Rawa Pasang Surut \\ Di Kalimantan Selatan}

FAO. 1974. Soil Map of the World, 1 : 5,000,000,10 Vol. Unesco, Paris.

Geyh, M.A., H.R. Kudres, and H. Streip. 1979. Sea-level Changes During The Late Pleistocene and Holocen in The Strait of Malacca. Nature 278: 441-443.

Kselik, R.A.L 1990. Water Management on Acid Sulphate Soils at Pulau Petak, Kalimantan. Dalam: AARDLAWOO. Paper Workshop on Acid Sulpgate Soil in The Humid Tropics, November, 20-22, 1990.AARDLAWOO. Bogor/Jakarta. Pp. 249-276.

Leiwakabessy, F.M. dan M. Wahjudin. 1979. Ketebalan gambut dan produksi padi. Prosiding Simposium Nasional III Pengembangan Daerah Pasang Surut di Indonesia. Palembang. 376-389 pp.

Maas, A. 1989. Acidity Characterizations of Peat Soils from West Kalimantan, Indonesia. ITC, Gent Belgium. (unpublished).

Noor, M. 2004. Lahan Rawa: Sifat dan Pengelolaan Tanah Bermasalah Sulfat Masam. Jakarta : PT. Raja Grafindo Persada. 241 hal.

Nugroho K., H. Van den Bosch, Holongphi, J. Michaelsen. 1998. Evaluation of water management strategis for sustainable land use of acid sulphate soil in coastal low land in the tropics. Agric. Research Dept. REPORT 157.Wageningan.

Purnomo, E., A. Mursyid, M. Syarwani. A. Jumberi, Y. Hashidoko. T. Hasegawa, S. Honma, dan M. Osaki. 2005. Phosphorus solubilizing microorganisms in the rhyzosphere of local rice varities grown without fertilizer on acid sulphate soils. Soil Sci. Plant Nutr. 51 (5).

Prasetyo, H., J.A.M. Janssen, and Alkasuma. 1990. Landscape and Soil Genesis in Pulau Petak, Kalimantan. Papers work shop on acid sulphate soils in the humid tropics. 20-22 November 1990. Bogor, Indonesia.

Shamshuddin, J., M. Syarwani, S. Fauziah, dan I. Van Ranst. 2004. A Laboratory study on pyrite oxidation in acid sulphate soils. Commun. Soil. Sci. Plant Anal. 35 (1 \& 2):117-129.

Suryadi, F.X., P.H.J. Hollanders, dand R.H. Susanto. 2010. Mathematical modeling on the operation of water control structures in a secondary block case study: Delta Saleh, South Sumatra. Hosted by the Canadian Society for Bioengineering (CSBE/SCGAB).Québec City, Canada June 13-17, 2010.

Widjaja-Adhi, I P.G. 1986. Pengelolaan Lahan Rawa Pasang Surut dan Lebak. J. Litbang Pertanian 5. Badan Litbang Pertanian. Jakarta.

Widjaja-Adhi, I P.G. dan T. Alihamsyah. 1998. Pengembang-an lahan pasang surut; Potensi, prospek, dan kendala serta teknologi pengelolaannya untuk pertanian. Prosiding Seminar Nasional dan Pertemuan Tahunan Komda HITI, 16-17 Desember 1998. hlm.51-72. 